\title{
Relationships between crown architecture and available irradiance in two cerrado species with different leaf phenologies
}

\author{
KARINE M. SANTOS ${ }^{1}$, HÉLDER N. CONSOLARO ${ }^{1}$, MARIA INÊS C. MORENO', \\ CARLOS HENRIQUE B.A. PRADO² and JOÃO PAULO SOUZA 3,4
}

(received: February 09, 2012; accepted: November 19, 2012)

\begin{abstract}
Relationships between crown architecture and available irradiance in two cerrado species with different leaf phenologies). Structural differences between cerrado species with different leaf phenologies are linked to crown architecture, leaf production, and biomass allocation to shoots and leaves. The present study characterized crown structures and the patterns of biomass allocation to leaves and shoots in two woody cerrado species with contrasting leaf phenologies and quantified the irradiance reaching their leaves to determine the best period during the day for photosynthetic activity. The shoots and leaves of five individuals of both Annona coriacea (deciduous) and Hymenaea stigonocarpa (evergreen) were collected along a $50 \mathrm{~m}$ transect in a cerrado fragment within the urban perimeter of Catalão - GO, to determine their patterns of biomass allocation in their crowns. The evergreen $H$. stigonocarpa had significantly higher mean values of shoot inclination (SI), petiole length (PL), leaf area (LA), leaf display index (LDI), and individual leaf area per shoot (ILA), while the deciduous species A. coriacea had significantly higher leaf numbers (LN). The more complex crown of $H$. stigonocarpa had shoots in more erect positions (orthotropic), with intense self-shading within shoots; A. coriacea, on the other hand, had slanting (plagiotropic) shoots in the crown, allowing similar irradiance levels to all leaf surfaces. The production of plagiotropic shoots by the deciduous species (A. coriacea) is a strategy that enables its use of incident sunlight early in the morning and preventing excessive water loss or excessive irradiance. Hymenaea stigonocarpa (an evergreen), by contrast, had orthotropic shoots and uses intense self-shading as a strategy to avoid excessive irradiance, especially at midday. Differences in crown architectures between evergreen and deciduous species of cerrado sensu stricto can therefore be viewed as adaptations to the environmental light regime.
\end{abstract}

Key words - biomass allocation, leaf area, leaf display index, orthotropic shoots, plagiotropic shoots

\section{INTRODUCTION}

The cerrado is the second largest vegetation type in Brazil, only surpassed by the Amazon forest (Ribeiro $\&$ Walter 2008), and it occupies approximately $23 \%$ of the total land area of that country (approximately 2,000,000 $\mathrm{km}^{2}$ ) (Macedo 1995). Cerrado sensu lato (or simply, cerrado) is the typical vegetation type of the central highlands of Brazil, occupying large portions of the states of Goiás and Minas Gerais and extending to Mato Grosso do Sul, Paraná and São Paulo states and the northeastern region of the country (Dias 1996).

The climate of the Cerrado biome is predominantly tropical, with well-defined warm and wet summers and cold and dry winters (Eiten 1979, Sarmiento 1984). The wide variations of woody and herbaceous vegetations within the Cerrado biome are associated with different

1. Universidade Federal de Goiás, Departamento de Ciências Biológicas, Av. Dr. Lamartine Pinto de Avelar, 1120, Setor Universitário, 75704-020 Catalão, GO, Brazil.

2. Universidade Federal de São Carlos, Departamento de Botânica, Rodovia Washington Luís, km 235, 13565-905 São Carlos, SP, Brazil.

3. Universidade Federal de Viçosa, Campus Florestal, Rodovia LMG 818, km 06, 35690-000 Florestal, MG, Brazil.

4. Corresponding author: joaopaulobio@hotmail.com soil types and topographies, making it one of the world's most diverse savanna vegetation types (Eiten 1979, Furley \& Ratter 1988). Topography, climate, and periodic fire events influence the structure and functioning of the various cerrado vegetation types in Brazil (Franco 2002, Damascos et al. 2005, Souza et al. 2011), and changes in the physical properties of the soil and its fertility result in variations in the physiognomy of the vegetation and to differences in plant productivity (Haridasan 2000), and that the species growing there have adopted numerous ecological strategies for establishment and survival.

The woody elements of cerrado sensu stricto vegetation show two distinct functional types in terms of leaf phenology (Paula 2002, Damascos et al. 2005): evergreen species, which are characterized by continuous leaf production over several months (Damascos et al. 2005, Lenza \& Klink 2006), retention of several leaf cohorts in their crowns throughout the year, and more intense shoot branching (Damascos et al. 2005, Souza et al. 2011); and deciduous species, which lose all their leaves during the dry period and demonstrate synchronous leaf flush at the end of the dry season. Regardless of differences in their leaf phenologies, plant species growing in seasonal environments (such as the savanna) must program leaf and shoot renewal to maximize survival and productivity (Damascos et al. 2005). 
Wide variations in crown architecture (i.e. branching patterns) result in leaves having different insertions onto their supporting shoots (Souza et al. 2009a, b) that have direct implications for light interception (Press 1999, Faslter \& Westoby 2003) and will therefore influence biomass distribution to the leaves and shoots. In general, species that demonstrate synchronous leaf flushing on plagiotropic shoots avoid self-shading and irradiance is more or less evenly distributed along the shoots (Kikuzawa et al. 1996, Souza et al. 2009a). Species with continuous leaf production, however, tend to have orthotropic shoots whose basal leaves receive less irradiance than the younger leaves at the shoot apex (Kikuzawa 2003, Souza et al. 2009a). According to Souza et al. (2009a), there is little data available concerning how leaf positions along the shoot or shoot inclination affect the incidence of light on the leaves, despite the wide variations in irradiance intensity within different cerrado phytophysiognomies. According to Werner et al. (2001), light absorption is higher among leaves that are positioned perpendicular to the sun, while vertical orientations will reduce light interception rates. High irradiance can lead to stress conditions in plants, with significant deviations from optimal survival conditions with effects at all levels of functional organization (Larcher 2000).

Plant species show different adaptations to local environment conditions, and Souza et al. (2009b) noted distinct biomass allocation patterns among leaves and shoots in woody cerrado species, with deciduous species allocating more biomass to their leaves (resulting in greater leaf areas) than to the shoots, while evergreen species that keep their leaves throughout the year allocated more biomass to their shoots. The strategy among deciduous species (that shed their foliage during the dry period) of greater biomass allocation to leaves exposed to greater irradiance levels results in larger photosynthetic surface areas (Souza et al. 2009b). Evergreen species, on the other hand, adopt a different strategy as they avoid significant self-shading within shoots.

Studies of resource allocation in native cerrado species are informative as these plants usually occur in nutrient-poor soils, and biomass allocations will reflect their survival strategies (Scheffer-Basso et al. 2002). Shading within the crowns of cerrado trees is influenced by the inclination of the branches (Souza et al. 2009a) and by patterns of biomass allocations between leaves and shoots (Souza et al. 2009b). In species with slanting shoots (where light incidence is equally distributed among all the leaves along the shoot), more biomass can be allocated to leaves than to shoots without significant increases in self-shading (Souza et al. 2009b). In contrast, species with erect shoots show heavy shading within the crown and they therefore allocate more biomass to shoots, with leaves that have reduced photosynthetic areas. Environmental disturbances (e.g., fire), however, can alter resource allocations for growth and, as a consequence, the biomass allocation patterns of the different species. The principal objective of this study was to characterize crown structures and the patterns of biomass allocations to leaves and shoots in cerrado species with distinct leaf phenologies. Specifically, we addressed the following questions: 1 ) do deciduous and evergreen species show distinct patterns of biomass allocation to their shoots and leaves? and 2) does shoot inclination affect the irradiance reaching the different leaves along the shoot? To answer these questions, we measured shoot inclinations and the patterns of biomass allocation to leaves and shoots in order to identify resource allocation optimization strategies within the crown and the influence of incident light on the crown structures of woody cerrado species.

\section{MATERIAL AND METHODS}

\section{Study area and climate}

The study was conducted between June/2010 and January/2011 in a remnant area of cerrado vegetation known locally as Pasto do Pedrinho (Pedrinho's Pasture) in the municipality of Catalão $\left(47^{\circ} 57^{\prime} 02^{\prime \prime}\right.$ to $47^{\circ} 56^{\prime} 30^{\prime \prime} \mathrm{W}$ and $18^{\circ} 09^{\prime} 45^{\prime \prime}$ to $18^{\circ} 09^{\prime} 16^{\prime \prime} \mathrm{S}$ ), Goiás State, Brazil. The study area occupies approximately 54 ha of predominantly cerrado sensu stricto vegetation, with patches of cerrado rupestre, cerrado denso, and gallery forest. The area was extensively used for cattle grazing before being transformed into a municipal park. Several research projects are currently being conducted at this site, and it is also open to public visitation and for recreational use. The regional climate is humid subtropical with a rainy summer and dry winter (Köeppen 1948). The average annual temperature is $22^{\circ} \mathrm{C}$ and the total annual precipitation is $1750 \mathrm{~mm}$, with rainfall concentrated from October to March (Toledo et al. 2004). The average temperature remained essentially constant during the study period, with low rainfall during the first months (June, July and August) that increased from the end of August/2010 until January/2011.

\section{Plant material and phenology}

The two species studied have different patterns of leaf deciduousness. Annona coriacea Mart. (Annonaceae), popularly known as araticum-do-cerrado, is found in the savannas of central Brazil (Almeida et al. 1998). Adult individuals can reach heights of 3-6 m and can occur in cerrado sites in the states of Bahia, São Paulo, Minas Gerais, Goiás, Mato Grosso, and Mato Grosso do Sul. It is 
a deciduous species (personal observation), losing all of its leaves for a brief period during the dry season (approximately three to four weeks). Hymenaea stigonocarpa Mart. ex Hayne (jatobá-do-cerrado, Fabaceae) is a woody species that can reach up to $6 \mathrm{~m}$ tall; it is an evergreen species and retains its leaves throughout the year with a relatively homogeneous distribution in cerrado areas (Lee \& Langenheim 1975).

The choice of $A$. coriacea and $H$. stigonocarpa was influenced by the numbers of individuals in the study area, their accessibility (proximity to a trail near one of the entrances to the site), and by the lack of prior studies about their crown architecture.

\section{Shoot selection and measurements of shoot growth}

We selected five adult individuals of each species with similar heights (determined by measuring their heights from the ground to the apex of the plant, and their stem diameters at breast height). Five shoots were marked per individual ( $n=25$ shoots per species) in June/2010 with colored-coded ribbons for identification during later visits. Shoot and leaf production were followed on a weekly basis during the dry season and at fifteen-day intervals during the rainy season.

The marked shoots were followed until the end of the growth seasons of both species to evaluate the environmental conditions they were exposed to and the factors that influenced shoot growth. The shoots were collected in January/2011 (in the morning) and packed in previously marked plastic bags, and subsequently removed to the laboratory.

\section{Leaf area, shoot and leaf dry mass, and shoot length}

After collection, the 45 shoots (25 of $H$. stigonocarpa and 20 of $A$. coriacea, the latter having five shoots less due to the death of one individual) were taken to the Integrated Laboratory of Zoology, Ecology and Botany (ILZEB) at the Federal University of Goiás - Campus Catalão. All of the leaves were removed from each shoot, and each leaf was scanned to determine its area using Image Pro software, version 4.0 (Media Cybernetics, USA). Total leaf area per shoot was determined by summing the leaf areas of all of the leaves along each shoot.

The same leaves used for the determinations of leaf area were dried at $60{ }^{\circ} \mathrm{C}$ to a constant weight (72 h) (Cornelissen et al. 2003) and weighed on an analytical balance to calculate total leaf dry mass per shoot. Shoot lengths were was measured with a millimeter ruler and their dry masses determined by drying at $60{ }^{\circ} \mathrm{C}$ for $72 \mathrm{~h}$ (Cornelissen et al. 2003) and weighing, following the same procedures used for the leaves.

\section{Shoot inclinations, leaf numbers per shoot, and crown parameters}

We evaluated 10 shoots per individual in 5 individuals per species ( $n=50$ shoots) randomly distributed over the tree crown (during June/2010, the first month of the study) to determine the angles of inclination of the shoots in relation to the horizon. The shoots examined had grown during the previous growing season, were generally located on the outside of the crown, and had fully expanded mature leaves. The angle between the shoot and the horizon was determined using a plumb line and a $2 \mathrm{~m}$ vertical bar and a protractor (Souza et al. 2009b).

All the leaves on each $\operatorname{shoot}(n=10$ shoots per individual) were counted, regardless of their size, shape, or leaf age, and the phyllotaxis was determined. The crown heights and diameters were determined using a tape measure. Irradiance into the crown (IIC) and irradiance outside the crown (IOC) were measured using a Parkinson Leaf Chamber connected to an IRGA (ADC, LCA-4, Hoddesdon, UK).

\section{Shoot-foliage relationships}

Measurements of biomass allocations to shoots and leaves followed the methodologies described by Yagi \& Kikuzawa (1999), Yagi (2000), and Souza et al. (2009b) and were used to identify patterns of biomass allocation and resource optimization within the crowns of species with contrasting leaf phenologies.

The following crown parameters were determined: 1) leaf display indices (LDI $\mathrm{cm}^{2} \mathrm{~cm}^{-1}$, total leaf area divided by shoot length); 2) leaf/shoot ratios (LSR, $\mathrm{g} \mathrm{g}^{-1}$, mass of leaves per shoot mass); 3) individual leaf areas (ILA $\mathrm{cm}^{2}$, total leaf area divided by leaf numbers), and; 4) leaf number densities (DLN, leaf $\mathrm{cm}^{-1}$, leaf number divided by shoot length).

\section{Statistical analyses}

The means and standard errors of the leaf numbers per shoot, leaf areas, leaf dry masses, shoot dry masses, shoot lengths, ILA, LDI, LSR, and DLN were calculated. The Student's t-test (Zar 1999) was used to calculate the differences between these parameters in the two woody species.

\section{RESULTS}

The evergreen species (Hymenaea stigonocarpa) had orthotropic shoots $\left(58^{\circ}\right)$, while the deciduous species (Annona coriacea) had plagiotropic shoots $\left(23^{\circ}\right.$ ) (table 1). Importantly, both the mean length of the petiole and the mean leaf area of the evergreen species were more than twice the values seen in the deciduous species (table 1). In contrast, the numbers of leaves on the evergreen species were significantly lower (table 1).

The combination of orthotropic shoots, alternate distichous phyllotaxis, and higher leaf areas resulted in strong shading at the bases of the shoots in the evergreen species (H. stigonocarpa) accounting for only $69 \%$ of the total irradiance (table 2); the shoot base in the deciduous species (A. coriacea), on the other hand, received nearly 
Table 1. Crown architecture parameters of two woody cerrado species with distinct leaf phenologies. (SI = shoot inclination; $\mathrm{PL}=$ petiole length; $\mathrm{IIC}=$ irradiance inside the crown; $\mathrm{IOC}=$ irradiance outside the crown; $\mathrm{LN}=$ leaf number; $\mathrm{LA}=$ leaf area; $\mathrm{SL}=$ shoot length). Different letters after the mean values in each column indicate significant differences between the species (Student's t-test, $P<0.05$ ).

\begin{tabular}{lccccccc}
\hline Species & $\begin{array}{c}\text { SI } \\
\left({ }^{\circ}\right)\end{array}$ & $\begin{array}{c}\text { PL } \\
(\mathrm{cm})\end{array}$ & $\begin{array}{c}\text { IIC } \\
\left(\mu \mathrm{mol} \mathrm{m}^{-2} \mathrm{~s}^{-1}\right)\end{array}$ & $\begin{array}{c}\text { IOC } \\
\left(\mu \mathrm{mol} \mathrm{m}^{-2} \mathrm{~s}^{-1}\right)\end{array}$ & LN & $\begin{array}{c}\text { LA } \\
\left(\mathrm{cm}^{2}\right)\end{array}$ & $\begin{array}{c}\text { SL } \\
(\mathrm{cm})\end{array}$ \\
\hline Annona coriacea & $23.1 \pm 1.0 \mathrm{~B}$ & $0.7 \pm 0.05 \mathrm{~B}$ & $392.4 \pm 90 \mathrm{~A}$ & $1270.8 \pm 54 \mathrm{~A}$ & $5.2 \pm 0.3 \mathrm{~A}$ & $210.1 \pm 22 \mathrm{~B}$ & $15.7 \pm 2.0 \mathrm{~A}$ \\
Hymenaea stigonocarpa & $58.0 \pm 2.0 \mathrm{~A}$ & $2.2 \pm 0.1 \mathrm{~A}$ & $399.6 \pm 90 \mathrm{~A}$ & $1247.4 \pm 72 \mathrm{~A}$ & $3.8 \pm 0.3 \mathrm{~B}$ & $491.2 \pm 50 \mathrm{~A}$ & $15.0 \pm 1.0 \mathrm{~A}$ \\
\hline
\end{tabular}

Table 2. Irradiance $\left(\mu \mathrm{mol} \mathrm{m} \mathrm{m}^{-2} \mathrm{~s}^{-1}\right)$ reaching basal and distal leaves in two woody cerrado species with distinct leaf phenologies. Different letters after the mean values in each row indicate significant differences between basal and distal leaves (Student's t-test, $P<0.05$ ).

\begin{tabular}{lcc}
\hline \multirow{2}{*}{ Species } & \multicolumn{2}{c}{ Leaf position } \\
\cline { 2 - 3 } & Basal & Distal \\
\hline Annona coriacea & $1045.8 \pm 90 \mathrm{~A}$ & $1234.8 \pm 72 \mathrm{~A}$ \\
Hymenaea stigonocarpa & $876.6 \pm 108 \mathrm{~B}$ & $1188 \pm 54 \mathrm{~A}$ \\
\hline
\end{tabular}

$82 \%$ of the total irradiance measured in the open area, and the distal end $97 \%$ (table 2).

The plagiotropic shoot of the deciduous species showed little variation in the amount of irradiance it received along its length (figure 1), while the orthotropic shoot of the evergreen species demonstrated a gradient of increasing irradiance from the shoot base to apex. The evergreen species also had a higher leaf display index

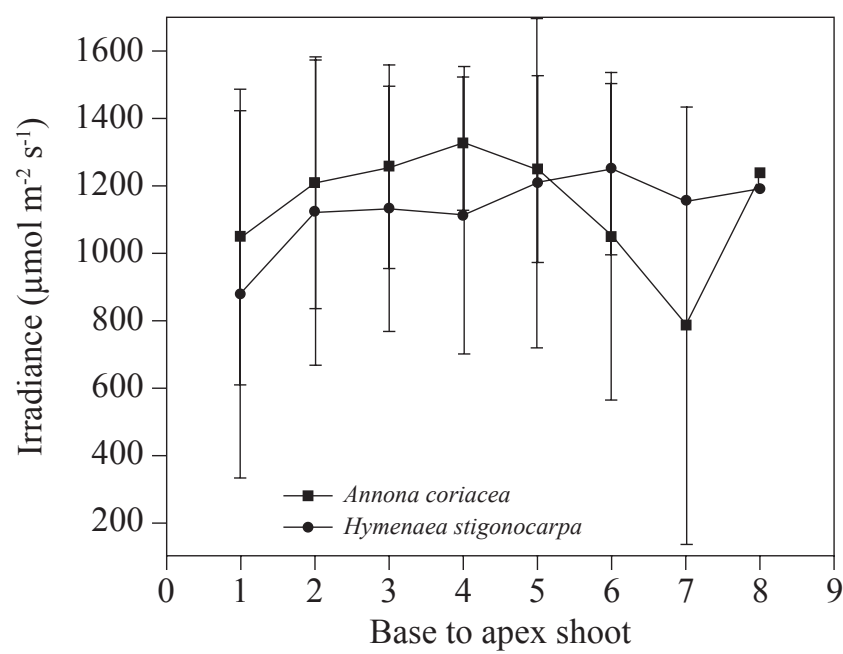

Figure 1. Photosynthetically active photon flux density $\left(\mu \mathrm{mol} \mathrm{m} \mathrm{m}^{-2} \mathrm{~s}^{-1}\right)$ along shoots of two woody cerrado species with distinct leaf phenologies. The numbers represent leaves along a single shoot $(1=$ the most basal leaf on the shoot, and $8=$ the most distal leaf on the shoot).
(LDI) and individual leaf area (ILA, leaf area divided by the number of leaves, table 3 ). All other biometric indexes were similar for both species (table 3 ).

The plagiotropic shoots of the deciduous species vary in terms of their global capture of radiation throughout the day (figure 2) and the deciduous species could use this irradiance for a longer period during the day. Additionally, the deciduous species could more

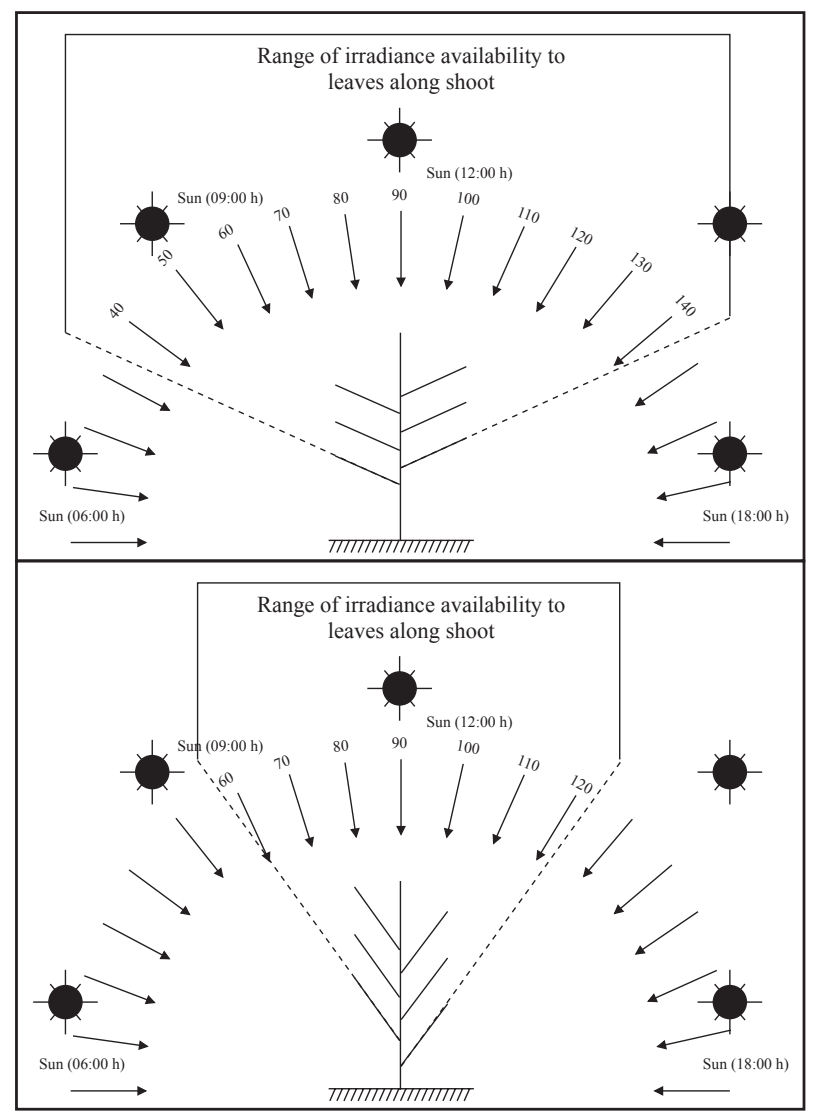

Figure 2. Irradiance available to leaves along shoots in two woody cerrado species with distinct leaf phenologies. Top: Annona coriacea (deciduous), bottom: Hymenaea stigonocarpa (evergreen). The available leaf irradiance was determined considering the shoot inclinations of the two cerrado species and the daily apparent movement of the sun during the dry season. 
Table 3. Shoot-foliage relationships in two woody cerrado species with distinct leaf phenologies. (LM = leaf mass; SM = shoot mass; LDI = leaf display index; DLN = density of leaf numbers; ILA = individual leaf area; LSR = leaf shoot ratio). Different letters after the mean values in each column indicate significant differences between the species (Student's t-test, $P<0.05$ ).

\begin{tabular}{lcccccc}
\hline Species & $\begin{array}{c}\text { LM } \\
(\mathrm{g})\end{array}$ & $\begin{array}{c}\text { SM } \\
(\mathrm{g})\end{array}$ & $\begin{array}{c}\text { LDI } \\
\left(\mathrm{cm}^{2}\right)\end{array}$ & $\begin{array}{c}\text { DLN } \\
\left(\mathrm{leaf} \mathrm{cm}^{-1}\right)\end{array}$ & $\begin{array}{c}\text { ILA } \\
\left(\mathrm{cm}^{2}\right)\end{array}$ & $\begin{array}{c}\text { LSR } \\
\left(\mathrm{g} \mathrm{g}^{-1}\right)\end{array}$ \\
\hline Annona coriacea & $7.1 \pm 1.0 \mathrm{~A}$ & $2.4 \pm 0.5 \mathrm{~A}$ & $16.9 \pm 3.0 \mathrm{~B}$ & $0.43 \pm 0.07 \mathrm{~A}$ & $42.9 \pm 5.0 \mathrm{~B}$ & $4.5 \pm 0.7 \mathrm{~A}$ \\
Hymenaea stigonocarpa & $6.6 \pm 0.5 \mathrm{~A}$ & $1.8 \pm 0.3 \mathrm{~A}$ & $39.4 \pm 4.0 \mathrm{~A}$ & $0.31 \pm 0.03 \mathrm{~A}$ & $139.0 \pm 14 \mathrm{~A}$ & $5.4 \pm 0.6 \mathrm{~A}$ \\
\hline
\end{tabular}

efficiently capture solar radiation during the early hours of day (08:00-10:00); the evergreen species, on the other hand, only captured solar radiation for shorter periods of time during the day (mainly at noon) because of the orthotropic orientation of its shoots (figure 2).

\section{DISCUSSION}

Species that can tolerate shading have leaves with higher leaf areas and lower specific weights in relation to sun leaves (Lambers et al. 1998). The evergreen species, H. stigonocarpa, had orthotropic shoots and higher leaf areas per shoot (LA), factors that increase self-shading along the same shoot (Souza et al. 2009a); greater leaf areas result in intense shading along shoots, but the greater leaf areas allow the upper leaves to intercept more solar radiation for photosynthetic purposes. Additionally, the alternate distichous phyllotaxis of evergreen species increases the shading of their basal leaves by distal leaves along the same shoot as they are aligned along the same plane. Souza et al. (2009a) studied six cerrado species with different characteristics of deciduousness and reported contrasting results: evergreen species had lower leaf areas along orthotropic shoots, resulting in less self-shading along that shoot. In contrast, the deciduous species had higher leaf areas along plagiotropic shoots, without intense selfshading (Souza et al. 2009a). The large leaf area in H. stigonocarpa, which increases the shading on its basal leaves, may represent a strategy to reduce transpiration in the older basal leaves, providing better conditions for photosynthesis.

The values of the crown architectural parameters of the species studied here were different from those found by Souza et al. (2009b), who reported that the deciduous species in their studies had higher leaf display indices (LDI), leaf densities per shoot (DLN), individual leaf areas (ILA), and leaf/shoot ratios (LSR) than the evergreen species. In the present study, H. stigonocarpa showed higher LDI and ILA values, reflecting the greater leaf area of this species. The study area (Pasto do Pedrinho) was burned during the study period, and several shoots and leaves of the H. stigonocarpa were lost. These plants subsequently allocated more resources (photosynthates) to increasing their photosynthetically active areas (more shoots and leaves), thus altering their crown architecture as a growth strategy. Given that this tree shows continuous leaf production and neo-formation of vegetative organs (personal observation), it altered biomass allocation to favor leaf formation to ensure continued growth.

Fire normally only affects woody cerrado vegetation to a limited degree due to the thick suberization of their shoots that insulates internal tissues (Miranda et al. 2002). Fires can kill woody individuals, however, if it reaches and severely burns the top of the tree. Tree mortality may increase after fire as an indirect consequence of herbivory and nutrient shortages (Cardinot 1998). Thus, although the fire in the study area did not kill any individuals of $H$. stigonocarpa it did alter patterns of biomass allocation to their leaves and shoots.

Deciduous cerrado species produce pre-formed leaves enclosed in buds (Damascos et al. 2005) and flush synchronously late in the dry season - thus reducing leaf loss to herbivory (which is usually much higher in the rainy season) (Marquis et al. 2002). The fire that occurred in the study area also affected the deciduous species A. coriacea, burning shoots with buds and preformed leaves (personal observation) - resulting in the loss of investments in bud formation for new shoots and leaves. The new vegetative buds that were subsequently produced had lower leaf areas and lower leaf densities per shoot as compared to the five deciduous species studied by Souza et al. (2009b).

The higher values of leaf area and shoot inclination of H. stigonocarpa (as compared to A. coriacea) resulted in intense self-shading despite the maintenance of its photosynthetic activity throughout the year. Its crown architecture (consisting mostly of orthotropic shoots that aid in avoiding excessive irradiance) does, however, demonstrate modifications that allow exposure of the basal leaves and enable the physiological functioning of 
the plant. This is possible because of the greater length of the petiole in $H$. stigonocarpa as compared to $A$. coriacea. This adjustment (petiole length) projects the basal leaves out words for better exposure to the incident solar radiation.

Cerrado is a characteristically open vegetation type (except for the dense woody cerradão physiognomy), but studies of the availability and use of incident solar radiation by its component species are still scarce (Franco 2002). The data presented here corroborated previous studies of shoot inclination in woody cerrado species in southeastern Brazil (Souza et al. 2009a, b) that reported that deciduous species have plagiotropic shoots (ranging from $40^{\circ}$ to $46^{\circ}$ ) while evergreen species have orthotropic shoots (ranging from $59^{\circ}$ to $66^{\circ}$ ). The shoot inclination of woody cerrado species appears to be the principal factor influencing crown morphology, and consequently for irradiance capture and carbon gains (Souza et al. 2009a, b). As seen here, woody deciduous species can take advantage of photosynthetically active solar radiation during the early morning hours - which is usually the best time for gas exchange in the cerrado environment (Prado \& Moraes 1997), while evergreen species have less opportunity to photosynthesize in the morning due to their shoot inclinations. It is important to note that we are discussing irradiance that reaches the shoots produced during the previous growing season and that carry mature leaves (located mostly on the periphery of the crown).

Both the orthotropic shoots of evergreen species and the plagiotropic shoots of deciduous species are exposed to excessive midday solar radiation as well as high temperatures and high evaporative demands (especially those shoots at the top of the crown) that can cause photoinhibition (Franco \& Lüttge 2002). Woody cerrado plants can reduce stomatal conductance, although this limits gas exchange and hence daily carbon gains. Evergreen species have fewer hours in the morning to perform photosynthesis as compared to deciduous individuals, as the older leaves along its shoots (the basal leaves) are shaded. The newer (distal) leaves of evergreen species have net photosynthetic rates similar to (or greater than) leaves along the shoots of deciduous species (Souza et al. 2009a). Irradiance availability and comparable leaf life spans result in similar net photosynthetic gains in both deciduous and evergreen cerrado species. Thus, cerrado species with differing leaf phenologies have developed different strategies to avoid excessive solar radiation that would otherwise result in excessive water losses. There adjustments of patterns of biomass allocation to leaves and shoots, and consequent changes in crown architecture, can be viewed as adaptations to the open vegetation phytophysiognomy of cerrado sensu stricto.

\section{REFERENCES}

Almeida SP, Proença CEB, Sano SM, Ribeiro JF. 1998. Cerrado: espécies vegetais úteis. Embrapa-CPAC, Planaltina.

Cardinot GK. 1998. Efeitos de diferentes regimes de queima nos padrões de rebrotamento de Kielmeyera coriacea Mart. e Roupala montana Aubl:, duas espécies típicas do cerrado. Dissertação de mestrado, Universidade de Brasília, Brasília.

Cornelissen JHC, Lavorel S, Garnier E, Díaz S, Buchmann N, Gurvich DE, Reich PB, Ter Steege H, Morgan HD, Vand Der Heijden MGA, Pausas JG, Poorter H. 2003. A handbook of protocols for standardised and easy measurement of plant functional traits worldwide. Australian Journal of Botany 51:335-380.

Damascos MA, Prado CHBA, Ronquim CC. 2005. Bud composition branching patterns and leaf phenologies in woody cerrado species. Annals of Botany 96: 1075-1084.

Dias BFS. 1996. Cerrados: uma caracterização. In Alternativas de desenvolvimento dos cerrados: manejo e conservação dos recursos naturais renováveis (Dias BFS, coord.). Fundação Pró-Natureza, Brasília, p.11-25.

Eiten G. 1979. Formas fisionômicas do Cerrado. Revista Brasileira de Botânica 2:139-148.

Falster DS, Westoby M. 2003. Leaf size and angle vary widely across species: what consequences for light interception? New Phytologist 158:509-525.

Franco AC. 2002. Ecophysiology of woody plants. In The cerrados of Brazil: ecology and natural history of a neotropical savanna (PS Oliveira, RJ Marquis, eds.). Columbia University Press, New York, p.178-197.

Franco AC, Lüttge U. 2002. Midday depression in savanna trees: coordinated adjustments in photochemical efficiency, photorespiration, $\mathrm{CO}_{2}$ assimilation and water use efficiency. Oecologia 131:356-365.

Furley PA, Ratter JA. 1988. The central Brazilian cerrado and their development. Journal of Biogeography 15: 97-108.

Haridasan M. 2000. Nutrição mineral de plantas nativas do cerrado. Revista Brasileira de Fisiologia Vegetal 12: 54-64.

Kikuzawa K, Koyama H, Umeki K, Lechowicz MJ. 1996. Some evidence for an adaptive linkage between leaf phenologies and shoot architecture in sampling trees. Functional Ecology 10:252-257.

Kikuzawa K. 2003. Phenological and morphological adaptations to the light environment in two woody and two herbaceous plant species. Functional Ecology 17:29-38. 
Köppen W. 1948. Climatologia: con un estudio de los climas de la Tierra. Fondo de Cultura Economica, México.

Lambers H, Chapim III FS, Pons TL. 1998. Plant physiological ecology. Springer, New York.

Larcher, W. 2000. Ecofisiologia vegetal. Rima, São Carlos.

Lee Y, Langenheim JH. 1975. Systematics of the genus Hymenaea L. (Leguminosae, Caesalpinioideae, Detarieae). University of California Publications in Botany, Vol. 69.

Lenza E, Klink CA. 2006. Comportamento fenológico de espécies lenhosas em um cerrado sentido restrito de Brasília, DF. Revista Brasileira de Botânica 29:627-638.

Macedo J. 1995. Os cerrados brasileiros: alternativa para a produção de alimentos no limiar do século XXI. Revista de Política Agrícola 6:11-18.

Marquis RJ, Morais HC, Diniz IR. 2002. Interactions among cerrado plants and their herbivores: unique or typical. In The cerrados of Brazil: ecology and natural history of a neotropical savanna (PS Oliveira, RJ Marquis, eds.). Columbia University Press, New York, p.306-328.

Miranda HS, Bustamante MMC, Miranda AC. 2002. The fire factor. In The cerrados of Brazil: ecology and natural history of a neotropical savanna (PS Oliveira, RJ Marquis, eds.). Columbia University Press, New York, p.51-68.

Paula NF. 2002. Capacidade fotossintética, deciduidade e teor de nitrogênio e fósforo em espécies lenhosas do cerrado. Tese de doutorado, Universidade Federal de São Carlos, São Carlos.

Prado CHBA, Moraes JAPV. 1997. Photosynthetic capacity and specific leaf mass in twenty woody species of Cerrado vegetation under field conditions. Photosynthetica 33:103-112.

Press MC. 1999. The functional significance of leaf structure: a search for generalizations. New Phytologist 143: 213-219.
Ribeiro JF, Walter BMT. 2008. As principais fitofisionomias do Bioma Cerrado. In Cerrado: ecologia e flora (SM Sano, SP Almeida, JF Ribeiro, eds.). Embrapa-CPAC, Planaltina, p.151-212.

Sarmiento G. 1984. The ecology of neotropical savannas. Harvard University Press, Cambridge.

Scheffer-Basso SM, Jacques AVA, Agnol MD. 2002. Alocação da biomassa e correlações morfofisiológicas em leguminosas forrageiras com hábitos e crescimento contrastantes. Scientia Agricola 59:629-634.

Souza JP, Prado CHBA, Damascos MA, Albino ALS. 2009a. Influence of shoot inclination on irradiance and morphophysiological leaf traits along shoots in cerrado trees with distinct leaf deciduousness. Brazilian Journal of Plant Physiology 21:281-289.

Souza JP, Prado CHBA, Albino ALS, Damascos MA. 2009 b. Shoot-foliage relationships in deciduous, semideciduous, and evergreen cerrado tree species. Brazilian Journal of Plant Physiology 21:75-86.

Souza JP, Prado CHBA, Albino ALS, Souza GM. 2011. Network analysis of tree crowns distinguishes functional groups of Cerrado species. Plant Ecology 212:11-19.

Toledo MCM, Oliveira SMB, Fontan F, Ferrari VC, Parseval P. 2004. Mineralogia, morfologia e cristaloquímica da monazita de Catalão (GO, Brasil). Revista Brasileira de Geociências 34:135-146.

Werner C, Ryel RJ, Correia O, Beyschlag W. 2001. Structural and functional variability within the canopy and its relevance for carbon gain and stress avoidance. Acta Oecologica 22:129-138.

Yagi T, Kikuzawa K. 1999. Patterns in size-related variations in current-year shoot structure in eight deciduous tree species. Journal of Plant Research 112:343-352.

Yagi T. 2000. Morphology and biomass allocation of currentyear shoots of ten tall species in cool temperate Japan. Journal of Plant Research 113:171-183.

Zar JH. 1999. Biostatistical analysis. 4th ed., Prentice Hall, Upper Saddle River. 
